\title{
日本海に面した港湾での高波高の発生予測に関する基礎的研究
}

\author{
久保 雅義*・小宗 多恵** \\ 斎藤 勝彦*・笹 健児***
}

\section{Basic Research on Forecast of High Waves in Ports and Harbours Facing to the Sea of Japan}

\author{
Masayoshi KUBO, Tae KOMUNE, \\ Katsuhiko SAITO and Kenji SASA
}

\begin{abstract}
In ports and harbors facing to the open sea, mooring ships have sometimes encountered severe wave condition in the winter, then the mooring ropes and fenders are broken. As the results, the accident of ship body damage has happened. In order to avoid such accidents, we should set the mooring criteria for the ship shifting to outside of the harbor. For the target N-port facing to the Sea of Japan, the critical offshore wave hight is known to be $5 \mathrm{~m}$ by our previous research, so we try to forecast the wave height before 2 or 4 hours earlier.

We propose several high wave forecasting methods using waves, winds and both data. If we use the 5 parameters method of wind and wave, we can forecast the critical conditions with $77 \%$ accuracy and 12 parameters method of wind, then $91 \%$ accuracy.
\end{abstract}

\section{1. 緒言}

近年、港湾における急激な波高上昇によって、係留中の船体動摇、係留索の切断、防舷材や船体の損傷 といった多数の被害が生じている(1)。このような被害への対策として、既設の係留施設を持つ港湾において は、適切な係留限界判断の運用が重要であると考朰れる。また、係留限界判断の要素として当該港湾海 域における気象・海象条件の設定、そして近隣港湾での波高変化の観察が挙げられる ${ }^{(2)}$ 。よって、本研究で は特定の港湾において係留限界判断のために必要となる詳細な波浪の特性について既存の統計データをも とに把握し、係留限界条件の設定や高波高予測について検討し若干の知見が得られたので報告する。

\section{2、波高予測と船舶の対応}

\section{1 重回帰分析による高波浪予測}

本研究では、特定の港湾として日本海側に位置するN港を挙げる。N港における高波高発生条件につい て 2 変数の相関等を調べた結果、高波高の発生は冬季に集中していることが分かった ${ }^{(2)(3)}$ 。

そこで、高波浪月別発生頻度が高かった11月、12月、1月、2 月に着目し波高予測を試みる。波高予測 式を立てる際には、重回帰分析を用いる。この重回帰分析においてはN港の 2 時間後、むしくは 4 時間後 の有義波高值を目的変数とし、N港の風速、有義波高データ(4)を説明変数として使用する。

\footnotetext{
* 正会員＼cjkstart神戸商船大学（产658 神戸市東灘区深江南町5-1-1）

** 非会員 郵船情報開発株式会社（テ105 東京都港区西新橋3-2-5 御成門郵船ビル）

***正会員＼cjkstart株式会社郵船海洋科学（开140 東京都品川区南品川2-3-6）
} 
本研究では、高波浪発生の月別特性に着目し波高予測の検討を進める。分析種類の例としては、1992年 12月の風速データを用いて重回帰分析を行い、波高予測式を立て、その式に1993年12月の風速データを代 入することにより、1993年12月の波高予測值を算出する、という方法を採っている。

また、重回帰分析により得られた予測式そのものでは、予測波高值が実際に観測される高波高值に対応 できない場合があった。そのため、本研究では重回帰分析によって得られた予測式（以下1次予測之呼ぶ） に、 $5 \mathrm{~m}$ 以上の波高値とそれに対応する 1 次予測值の比率 1.35 をか忛た予測式（以下 2 次予測と呼ぶ）を 用いることによって、実際に観測される高波浪に対応できるようにした。

この1.35といら比率は、1992年のデータを、そのまま予測式に代入して得た予測波高と $5 \mathrm{~m}$ 上の観測 波高との比率の平均値として得られた值である。

2.2 波高予测と船舶の港外避泊準備について

従来の波、風そして気圧分布を用いた特定地点での波高予測の研究(5)(6)では 6 時間後又は12時間後予測が 多いが、これらの研究では海上工事を主たる対象としており、この場合には工事の準備等でこのようにか なりの長時間予報が要求されているものと考えられる。しかしこの場合は当然のことであるが予測が実際 の観測波高よりも遅れる等の問題を抱えている。特に急激な波の立ち上がりにおいてはこの遅れが顕著に 出ることが指摘されている。このような時間遅れを解消するために対象港よりも南西に位置する他の港の 情報を変数 ${ }^{(7)}$ として使用する方法も提案されているが、常に情報を交換することはそれなりに労力を伴うこ とになる。

そこで本研究では港内係留船の港外避泊判断への波高予測に利用対象を絞った。港外避泊を行う場合の 準備は 2 時間程度 ${ }^{(8)}$ であることが分かっているので、予測時間を従来よりも短くして 4 時間又は 2 時間に設 定した。さらに一般的な波高值そのものの予測でなく予測波高が $5 \mathrm{~m}^{(3)}$ を越えるか否かに焦点を当てて以下 の検討を進めている。

このように本研究では波高予測式の精度を上げるために、主として予測する時点の 2 時間前の各データ を用いている。つまり、 $5 \mathrm{~m}$ といら予測波高值が得られた時点では、実際の観測波高值が $5 \mathrm{~m}$ に達するま でに 2 時間の余裕しかなく、事前準備無しでは係留限界状態への迅速な対応が困難となることが予想され る。よって、本研究での高波浪予測を利用する場合は、波高が $4 \mathrm{~m}$ を越える点を事前の判断点とし、その 時点で港内に係留している船舶は港外避泊準備等を実施するものとする。そして、この状態で 2 時間毎の 波高予測を行い、2 時間後の予測值が $5 \mathrm{~m}$ を越えれば、即港外避泊を実行することを前提として以下の議 論を進める。

2.3 予測波高のとらえ方

図 1 に予測波高の捉え方を説明する。点線は観測波高、太実線は 2 次予測波高を表す。現時点を仓とす ると、今から 2 時間後に波高は $(563 \mathrm{~cm})$ になると予測される。この場合、実際には 2 時間後の観測波高

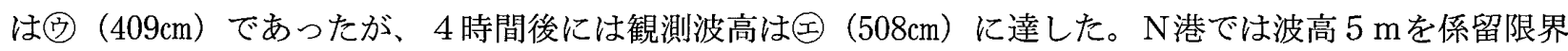
の目安としていることを考慮すると、予測波高と観測波高が $5 \mathrm{~m}$ を越える点に 2 時間のずれが生じたもの の、2 時間分安全側の予測ができたことになる。

つまり、この場合の予測は成功したと判断できる。 以下、このような判定を各場合毎に行っていく。

\section{3. 観測波高の時系列と各種予測波高の 時系列の比較}

以下に於いて各種予測手法每に観測值の時系列 と予測値の時系列との比較を行うが、全てのケー スについての議論はページ数の関係で出来ないの で、ここでは代表的な 3 つ例について考察を行 う。な抢以下で風速や波を 5 個または10個用いる 場合を、省略して 5 变数、または10変数としてい る。

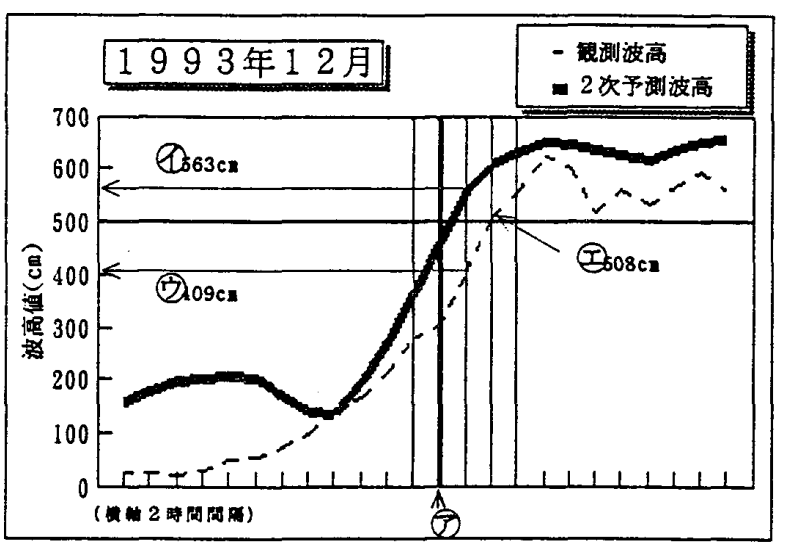

図 1 予測波高の捉光方 


\section{1 風速データを利用した予測}

（1） 5 変数を用いての 4 時間前予測の場合

係留限界状態への対応可能時間としては、およそ 4 時間が妥当であると考えられる。よって、まず予測 する時点の 4 時間から12時間前の5つのデータを用いて予測式を立てることを試みた。図 $2(\mathrm{a})$ に 2 次予 測波高が 5 m近くになるケースを挙げる。図において、点線は観測波高、細実線は 1 次了測波高、太実線 は2 次予測波高を表している。以下にこれら各ケースについての考察を記す。

2 次予測では、2月13日18時に波高が $5 \mathrm{~m}$ に達する。しかし、実際には観測波高は $5 \mathrm{~m}$ 達していない。 よって、この場合はしなくてよい緊急出港を行ったことで、費用損失を生じたことになる。

11月28日に観測波高は $5 \mathrm{~m}$ に達する。2 次予測では、その 4 時間前に $5 \mathrm{~m}$ に達すると予測される。よっ て、この場合 2 次子測は成功。

12月11日20時に観測波高は $5 \mathrm{~m}$ に達する。2 次予測では、その 4 時間後に波高が $5 \mathrm{~m}$ に達する。よって、 この場合の 2 次予測は危険側となり失敗。

これらの図から、予測する時点の 4 時間前のデータを用いて予測式を立てると、次のような問題が生じ ることが分かった。

(1)12月11日のように、波の立ち上がりが急な場合には、予測值として高波浪をとらえられない。 (2)実際の観測波に比べ予測波が遅れて出現する。

これらの問題を考慮し、以後の予測では、予測する時点の 2 時間前までのデータを用いて予測式を立て ることにする。

(2) 5 変数を用いての 2 時間前予測の場合

図 2 (b) に観測值波高または子測波高が $5 \mathrm{~m}$ 近くになる風速 5 変数による予測例を上げる。

2 次予測では、2 月13日18時に波高が $5 \mathrm{~m}$ を越える。しかし、実際には観測波高は $5 \mathrm{~m}$ 達していない。 よって、この場合は費用損失を生じる。

11月28日12時に観測波高は $5 \mathrm{~m}$ に達している。2 次予測では、その 6 時間前に $5 \mathrm{~m}$ 予測している。よ って、この場合の 2 次予測は成功。

12月11日16時から18時の間に観測波高は $5 \mathrm{~m}$ に達している。2 次予測では、その 2 時間後に $5 \mathrm{~m}$ に達し ている。よって、この場合の 2 次予測は危険側となり失敗。しかし 4 時間前予测よりは $5 \mathrm{~m}$ に達する時刻 の予測は早まっており改善されている。

(3) 12 変数の場合

図 2（c）に観測波高または予測波高が $5 \mathrm{~m}$ 近くとなる風速12変数による予測例を示す。全般的に先の 5 変数の場合と比較すると、観測波高の細かい上下の変化に対応できないといら点で劣っている。観測波高 変化では、そのような細かい上下の変化の途中で $5 \mathrm{~m}$ に達することがある。以下に 2 次子測波高が $5 \mathrm{~m}$ 索 越える各ケースについて考察を記す。

2 次了測では、2月10日16時に波高が $5 \mathrm{~m}$ に達している。しかし、実際には観測波高は $5 \mathrm{~m} に$ 達してい ない。よって、この場合は費用損失を生じる。

11月28日 12 時に観測波高は $5 \mathrm{~m}$ に達する。2 次予測では、その 4 時間前に $5 \mathrm{~m}$ に達すると予測される。 よって、この場合の 2 次予測は成功。

12月11日18時に観測波高は $5 \mathrm{~m}$ 越える。2 次予測では、その 2 時間後に $5 \mathrm{~m}$ 越えると予測される。よ って、この場合の 2 次予測は危険側となり失敗。

このように 3 ケースの事例で見る限りは変数を増やしても 5 変数の場合と傾向はそれほど大きく変わら ないが、この方法については後ほどさらに検討を加える。

3.2 有義波高データを利用した予測

図 2 (d)と（e ）に示すように、全般的に有義波高データを用いた 1 次予測は観測波高に非常に近い值を 取りながら変化する。しかしこの 1 次予測波高の変化は観測波高の後を追う形をとる。このため波高の予 測による係留限界の判断という目的が達成されない。このような問題については文献 5、6、7において も指摘されているところである。以下 5 変数と 10 変数を用いた場合の予測結果を示す。

(1) 5 変数の場合

図 2 (d) に 5 変数の場合の例を示す。 

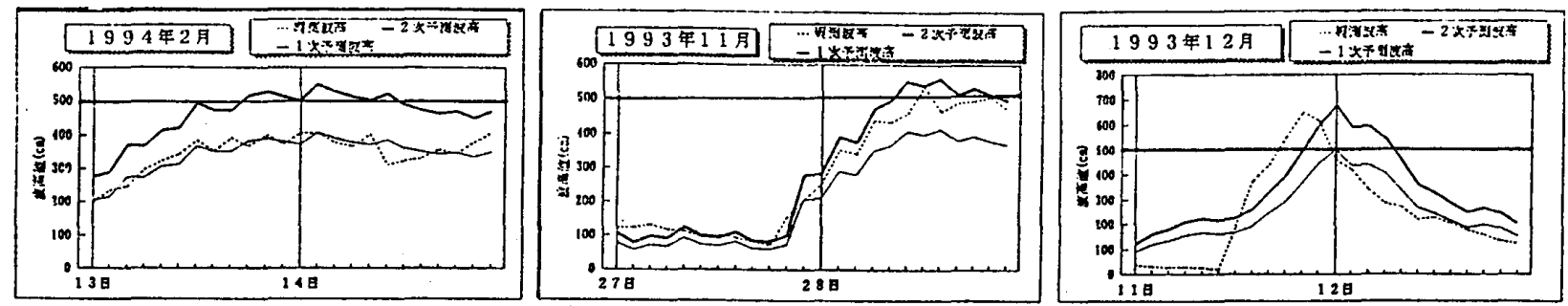

(a)風, $4 \mathrm{~h}$ 後.5変数
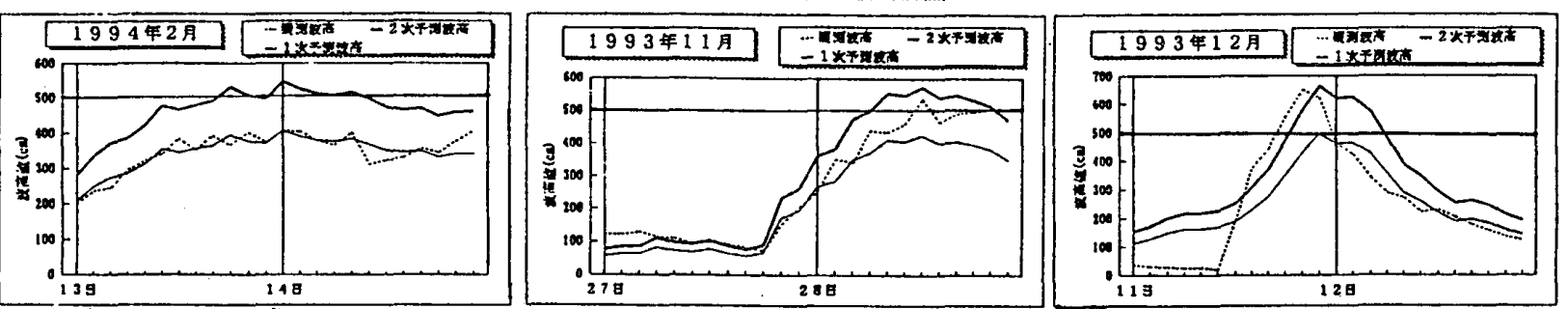

(b)風. 2 h 後. 5 变数
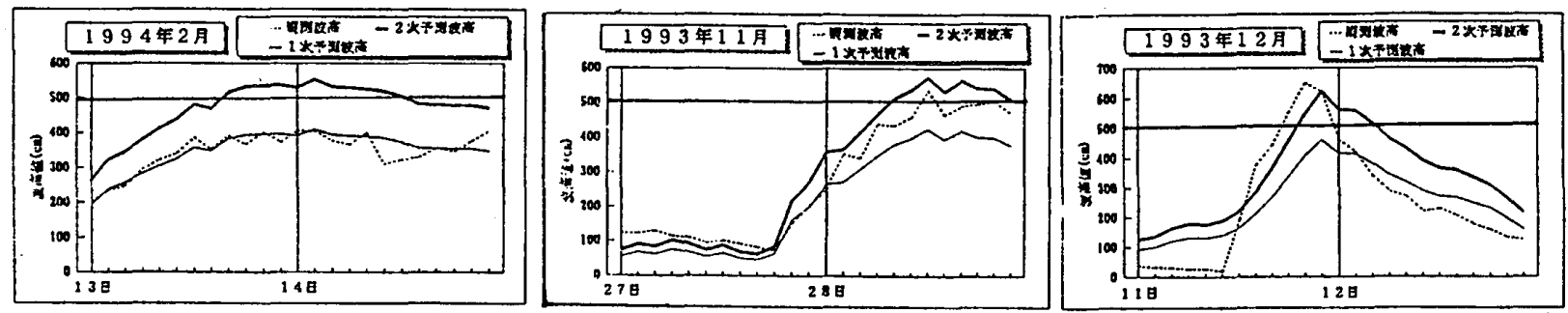

(c)風，2h後，12泟数
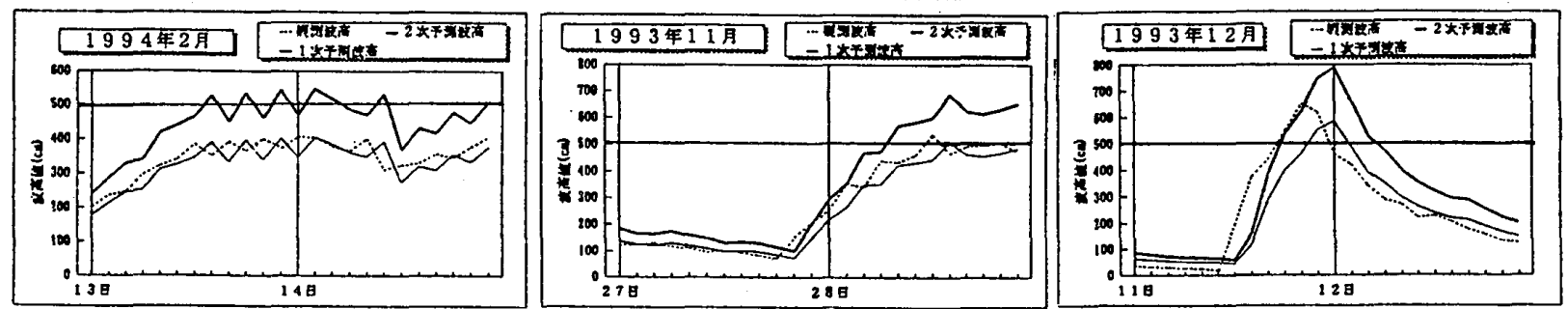

(d)波, 2 h後,5贸数
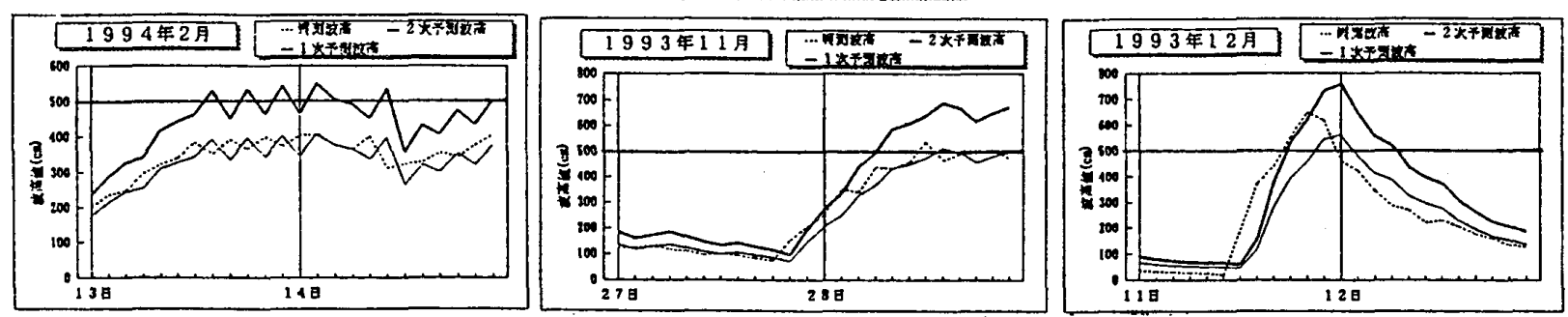

(e)波, 2 h後，10变数
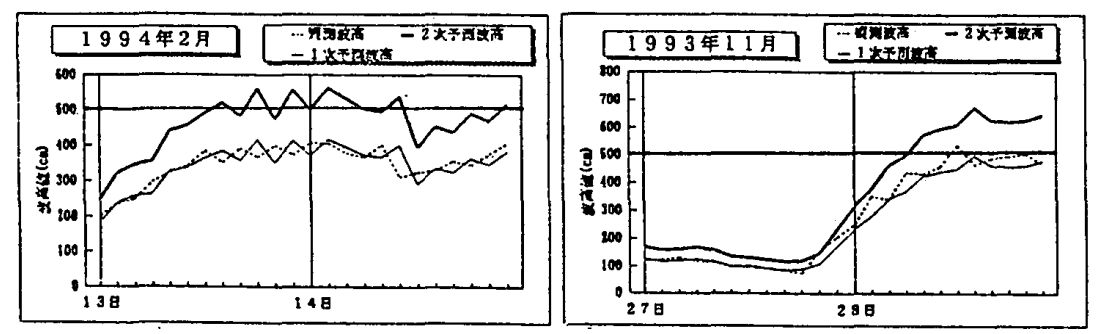

[f 風波, $2 \mathrm{~h}$ 㷋, 5 变数
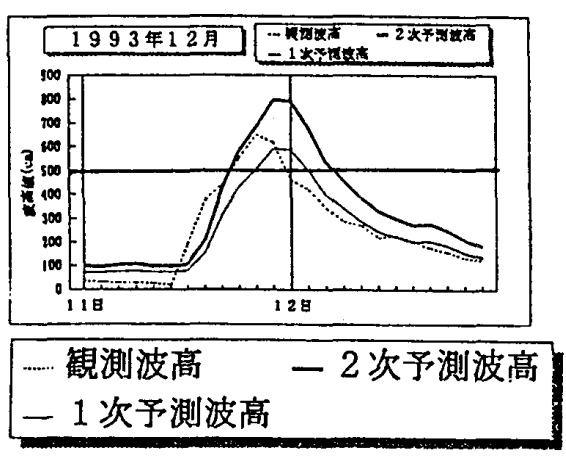

図 2 予測手法毎の観測波高と予測波高の時間変化 
2 次予測では、2 月13日14時に波高が $5 \mathrm{~m}$ に達している。しかし、実際には観測波高は $5 \mathrm{~m}$ に達してい ない。よって、この場合は費用損失を生じる。

11月28日 12 時に観測波高が $5 \mathrm{~m}$ に達する。 2 次予測では、その 4 時間前に予測可能である。よって、こ の場合の 2 次子測は成功。

12月11日18時に観測波高は $5 \mathrm{~m}$ に達する。図では少し遅れて波高は推移しているが、2 次子測でも同時 刻に波高值は $5 \mathrm{~m}$ に達する。よって、この場合の 2 次予測は成功。風を用いた場合には出来なかった予測 が可能になった点で進歩が見られるといえよう。

(2) 10 変数の場合

図 2 ( e ) に、この場合の 3 例を示す。

2 次予測では、 2 月 13 日14時に波高が $5 \mathrm{~m}$ に達している。しかし、実際には観測波高は $5 \mathrm{~m}$ に達してい ない。よって、この場合は費用損失を生じる。

11月28日12時に観測波高は $5 \mathrm{~m}$ に達する。 2 次予測では、その 8 時間前に予測可能である。よって、こ の場合の 2 次予測は成功。

12月11日18時に観測波高は $5 \mathrm{~m}$ に達する。2 次予測でも同時刻に波高が $5 \mathrm{~m}$ に達する。よって、この場 合の 2 次予測は成功。

10変数を用いると、予測波高は波高変化の全体をとらえる傾向が強くなる。これは風の場合と同じ傾向 である。

3.3 有義波高データと風速データを併用した予測

図 2(f)にこの場合の計算例を示す。

2 次予測では、 2 月 13 日14時に波高が $5 \mathrm{~m}$ に達 する。しかし、実際には観測波高は $5 \mathrm{~m}$ に達して いない。よって、この場合は費用損失を生じたこ とになる。

11月28日12時に観測波高は $5 \mathrm{~m}$ に達する。2 次 予測では、その 6 時間前に予測可能である。よっ て、この場合の 2 次予測は成功。

12月11日18時に観測波高は $5 \mathrm{~m}$ を越える。2 次 予測でも同時刻に波高が $5 \mathrm{~m}$ を越えている。よっ て、この場合の 2 次予測は成功。

風速データと波高データを併用しているために 上記のどの場合よりも予測は良くなっている。波 のみの予測よりも予測が良くなっているので、こ れについてもさらに以下で検討を加える。

\section{4. 高波高予測の評価と予測精度の向上}

\section{1 高波高予測の評価}

表 1 に、 6 種類の 2 次予測による観測波高の全 予測結果を示す。この場合の記号( $， \bigcirc 、 \triangle 、 \times$ の意味を以下に示す。

予測波高が観測波高よりも早い時刻に $5 \mathrm{~m}$ 以上 を予測し、観測波高も $5 \mathrm{~m}$ を越えた場合、予測は 成功と評価する。この場合の記号を(0で表す。

観測波高に対して 2 次予測波高が $5 \mathrm{~m}$ 未満を正 しく子測し、このため費用損失を生まなかった場 合、記号は○で表す。この場合には、観測波高が 極大值を持った時のみの比較でなくその前後にお
表 1 各種予測の避泊判別結果

\begin{tabular}{|c|c|c|c|c|c|c|c|c|}
\hline \multirow{3}{*}{ 月 } & \multirow{3}{*}{ 日 } & \multirow{3}{*}{$\begin{array}{l}\text { 番号 } \\
\text { 予列 } \\
\end{array}$} & \multicolumn{3}{|c|}{ 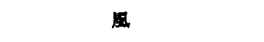 } & \multicolumn{2}{|l|}{ 波 } & \multirow{2}{*}{$\frac{\text { 盛之波 }}{2 \text { 時周後 }}$} \\
\hline & & & \multirow{2}{*}{ 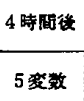 } & \multicolumn{2}{|c|}{2 時間復 } & \multicolumn{2}{|c|}{2 時图得 } & \\
\hline & & & & 5 要教 & 12 3) & 5 绞数 & 10 管数 & 5 要数 \\
\hline & $2-3$ & 1 & 0 & 0 & 0 & 0 & 0 & 0 \\
\hline & $4-5$ & 2 & (-) & $x$ & $x$ & () & (-) & (-) \\
\hline 1 & $6-7$ & 3 & $x$ & (ㅇ & $x$ & (c) & ( ) & (1) \\
\hline & $14-15$ & 4 & 0 & 0 & 0 & 0 & 0 & 0 \\
\hline & $17-19$ & 5 & $x$ & $x$ & (c) & (-) & (-) & (0) \\
\hline & 23 & 6 & 0 & 0 & 0 & 0 & $\Delta$ & 0 \\
\hline \multirow{5}{*}{2} & $1-2$ & 7 & $x$ & (c) & (0) & (0) & (-) & (1) \\
\hline & $7-8$ & 8 & 0 & 0 & 0 & 0 & 0 & 0 \\
\hline & $9-10$ & 9 & $\Delta$ & $\Delta$ & 0 & $\Delta$ & $\Delta$ & $\Delta$ \\
\hline & $12-14$ & 10 & $\Delta$ & $\Delta$ & $\Delta$ & $\Delta$ & $\Delta$ & $\Delta$ \\
\hline & $21-22$ & 11 & $\times$ & (0) & $x$ & 0 & (-) & (2) \\
\hline \multirow{3}{*}{11} & $21-22$ & 12 & (0) & (2) & () & () & (-) & (-) \\
\hline & $23-24$ & 13 & $\Delta$ & $\Delta$ & $\Delta$ & $\Delta$ & $\Delta$ & $\Delta$ \\
\hline & $27-28$ & 14 & @) & (c) & (-) & (-) & () & (1) \\
\hline \multirow{8}{*}{12} & 1 & 15 & 0 & 0 & 0 & 0 & 0 & 0 \\
\hline & $2-3$ & 16 & 0 & 0 & 0 & 0 & 0 & 0 \\
\hline & $4-5$ & 17 & 0 & 0 & 0 & 0 & 0 & 0 \\
\hline & 11 & 18 & $x$ & $\times$ & $x$ & (-) & (c) & (-) \\
\hline & $14-15$ & 19 & $\Delta$ & $\Delta$ & $\Delta$ & $\Delta$ & $\Delta$ & $\Delta$ \\
\hline & 17 & 20 & (-) & () & (2) & $x$ & $x$ & ○) \\
\hline & $21-22$ & 21 & (c) & (-) & (c) & $x$ & $x$ & ○ \\
\hline & $27-28$ & 22 & $\Delta$ & $\Delta$ & 0 & $\Delta$ & $\Delta$ & $\Delta$ \\
\hline
\end{tabular}


いても 2 次予測波高が $5 \mathrm{~m}$ を越えないことを条件としている。

観測波高は $5 \mathrm{~m}$ 以下なのに、2 次予測波高が $5 \mathrm{~m}$ 以上で港外避泊を行った場合には費用損失を生む。し かしこの場合は安全側の処置であり失敗ではないので、記号としては

観測波高が $5 \mathrm{~m}$ を越えるのに、2 次予測波高がこれを早めに予測できなかった場合には港内係留船は危 険な状態になる。この場合の記号として×で表す。

表 1 より 4 時間後の予測はかなり精度が悪くなることが分かる。

風による予測の場合と波による予測の場合では、予測にかなり影著な差が出ることが分かる。例えば予 測番号 2、18において風による予測は失敗しているが、波による予測では成功している。反対に予測番号 20、21では波による予測は失敗しているが、風による予測は成功している。このように両者の予測にはか なり違いがあることが分かる。

風と波の両方を説明変数として使用した場合は両者の良いところが生かされて、それぞれ単独の場合よ りむかなり予測が成功している。先ほど示した予測番号 $2 、 18 、 20 、 21$ は全て成功している。さらにこの 予測では、費用損失発生 $(\Delta)$ は 5 回あるが、予測危険側失敗 $(\times)$ はない。その意味では、この予測手 法は安全側であり、捨てがたい面を有していると言えよう。

以上の 2 次予測波高を横軸に、観測波高を縦軸にとって表すと図 3 のようになる。図には両者が一致し た場合の原点を通る勾配 1 の直線も示している。これらの結果より今回の予測波高は観測值よりかなり大 きめに出ていることが分かる。この傾向は波高が小さいところで特に顕著である。

つぎに@と○を予測の成功と見なして、各予測手法每の成功数を全予測数（22個）で割ることによって 成功率を定義する。同様にして費用損失率、失敗率を定義する。これらをまとめて表 2 に示す。これによ れば、風速を用いる予測の場合は 12 変数を用いた予測で $68 \%$ の成功率となり、波と風をそれぞれ 5 变数用 いる場合は77\%という高い成功率を得た。

そこで以下では風速12変数の場合と波と風 5 変数を用いた予測についてさらなる改良を試みる。

4.2 予測精度向上のための指標の導入

ここでは観測波高の時系列が $2 \mathrm{~m}$ 以下で極小值を取る時刻から、つぎに $2 \mathrm{~m}$ 以下で極小值を取る時刻ま
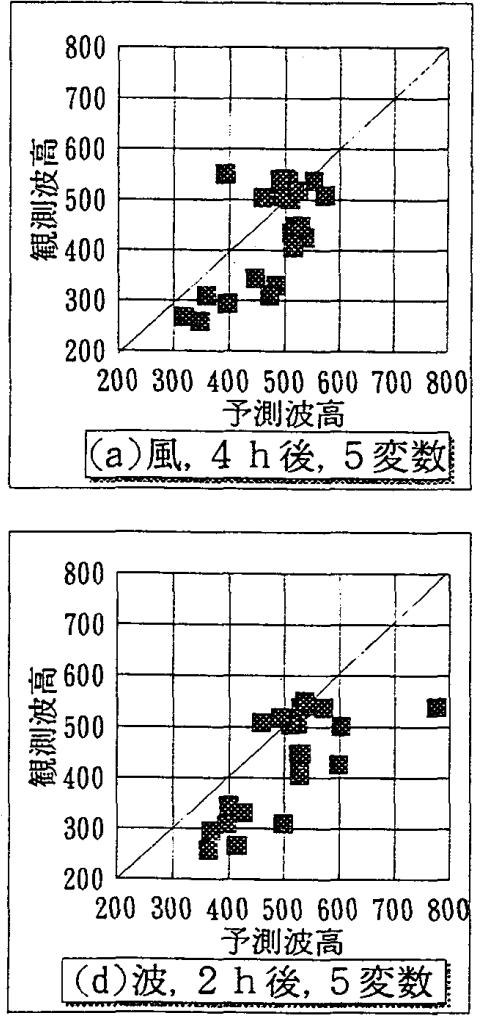
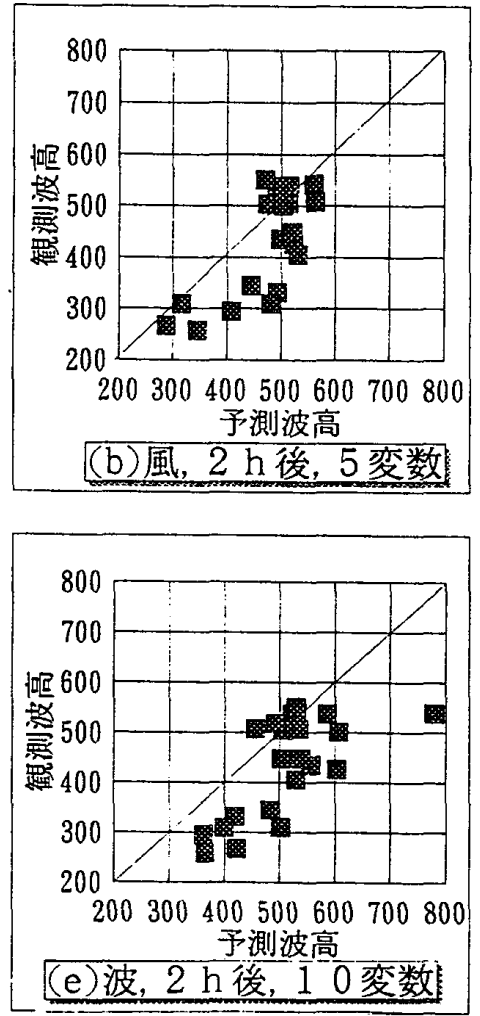
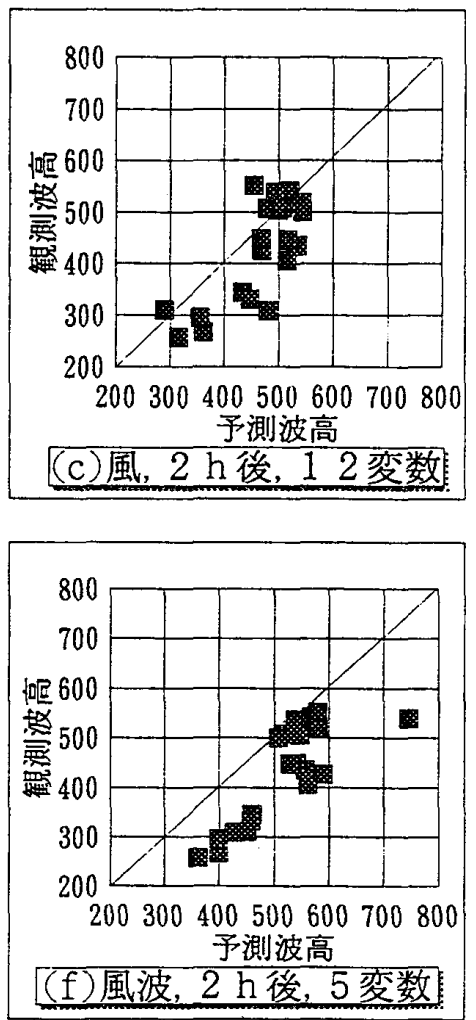

図 32 次予測波高と観測波高との比較 
でを1ケースとしている ${ }^{(3)}$ 。以下では次の 4 項目を 用いて検討を行う。

極小值

各ケースとして抽出したデータ内での最小波高 極大值

各ケースとして抽出したデータ内での最大波高 波高増加率

極小観測波高から次の観測波高まで 2 時間にお ける波高の増加率

平均 2 乗誤差

1 次予測では極大值が小さめに出ることは既に 述べた。その対応策として1.35倍すれば予測値が 観測值よりも遅れることは防げても、当然のこと であるが大きめに出ることも生じる。つまり 2 次 予測を重視することは費用損失を生じる場合が増 える可能性を秘めている。

費用損失を生じる場合の時系列波形をよく見る と観測波形と 1 次予測波形とが時間遅れは多少あ るものの両者は非常に良く似ていることに気付く。 上で例として示した図 2 の 2 月13日から14日の波 高変化はその代表例である。そこで極小值からの 観測值と 1 次予測值とのずれの累積值を指標とし て検討する。このような指標として、ここでは平 均 2 乗誤差 $a$ を用いることにした。

$$
a=\frac{\sum\left\{H_{0}(i)-H_{E}(i)\right\}^{2}}{N} \quad i=1,2,,,,,, N
$$

ここに $H_{0}(i)$ は $i$ 番目の観測波高 $(\mathrm{cm}) 、 H_{E}(i)$ は $i$ 番目の 1 次予測波高 $(\mathrm{cm}) 、 i=1$ は観測波高の 極小值に対応し、Nはデータ個数である。

\section{（1） 風速12変数の場合の新たな判別}

風速12変数モデルの全体的な傾向をつかむため に、極小から極大に至る22ケースについての性質 を表 3 に示す。

表 3 における観測波高と対応する 2 次予測波高 值法それぞれ以下のように決めている。の場合 は観測極大波高と対応する時刻もしくはそれ以前 に $5 \mathrm{~m}$ を越えた時の值を、○と $\triangle$ 場合は観測極 大波高值前後における極大値を、そして×の場合 は観測極大波高と対応する時刻での極大值を示し ている。

重回帰式に基づく波高予測は滑らかな波高变化

波高予測が著しく遅れることが分かっている。特に風速データによる場合は予測の遅れが著しい。この波 高急成長の遅れを取り戻すために 2 次予測波高に何らかの遅れ分を加算すれば追従するであるう事はある 程度予想できることである。そこで以下のような判別基準を導入する。この基準は港外避泊判断時期の遅 れ回避に有益である。 
第 1 基準：極小值における波高増加率が $100 \mathrm{~cm} / 2 \mathrm{~h}$ 以上で、 2 次予測值が $4 \mathrm{~m}$ 台に達した段階で $a$ が5000 を越え始めた場合には、2 次予測波高值に $50 \mathrm{~cm}$ を加えた值を持って採用予測波高值とする。もし $a$ が5000 を越えなければ第 2 基準に従う。

さらに費用損失が起こる場合には先に述べたように平均 2 乗誤差が小さいので費用損失回避の基準とし て以下の判別基準を導入する。

第 2 基準： $a$ が1000未満であれば 1 次予測を採用する。 $a$ が1000以上であれば 2 次予測を採用する。

つぎに、図 4 に判別の過程を示す。まず、観測值が得られた場合、第 1 基準で予測波高を算定する。も し、採用予測值が $5 \mathrm{~m}$ を越えれば緊急出港する。つぎに、第 2 基準で予測波高を算定する。この場合も採 用予測值が $5 \mathrm{~m}$ を越えれば緊急出港する。この計算を 2 時間毎に繰り返す。

図 5 に例を示す。12月 1 日の例では 12 時に極小值を取り、この時の波高変化率は $105 \mathrm{~cm} / 2 h$ となる。この ため第 1 基準に従って判断を開始する。2 次予測は 18 時に $4 \mathrm{~m}$ を越え始めるが 16 時の $a$ は 5000 以下なので、 第 2 基準により判定する。

12月11日の例では20時に 2 次予測波高が $4 \mathrm{~m}$ を越える。18時の $a$ は 18000 で5000を越えるので 2 次予測波 高に $50 \mathrm{~cm}$ 加え採用波高 $504 \mathrm{~cm}$ で $5 \mathrm{~m}$ を越えるため避泊を開始する。

12月15日の例では 2 次予測波高が 8 時に $5 \mathrm{~m}$ を越える。しかし 6 時の $a$ は 750 であり、1000以下であるの で 1 次波高を採用波高として避泊は行わない。

上記に打いて $a$ として色々な值を閾值として設 定したが、これらの值は限られた港に打汀る值で あって必ずしも普遍性を持つ值か否かは現段階で は不明である。この值の普遍性については今後の 課題としておく。しかしこの $a$ を用いることによ り、用いない時よりも優れた結果が出ることは明 らかであり、その意味において $a$ の有効性は明ら かである。

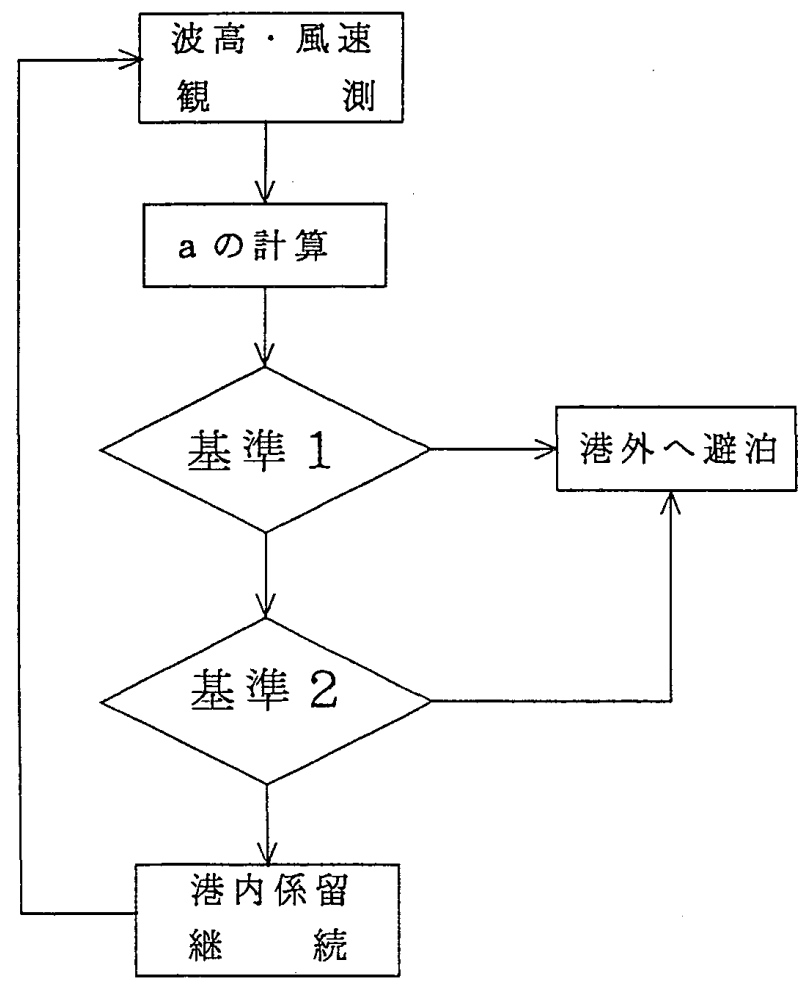

図 4 港内係留と港外避泊の判別フロー
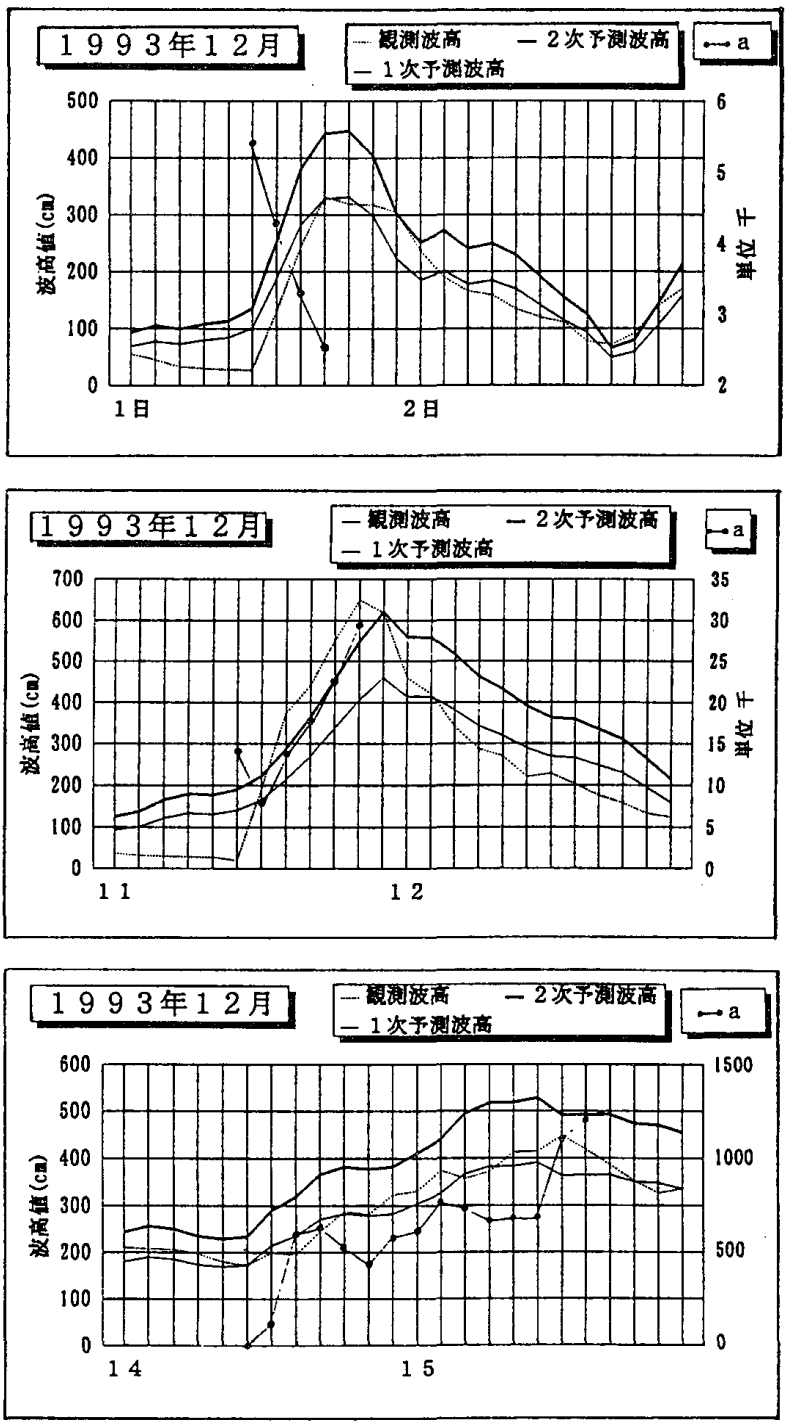

図 5 風速12変数を用いた予測手法に於ける 平均 2 乗誤差と予測波高との関係 
このように 2 つの判別基準を設けて、波高を評 価し直した結果を表 3 によしている。この判別 基準の設置により、予測成功（@） 6 回 -9 回、 費用損失回避 $(\bigcirc) 9$ 回一11回、費用損失発生 $(\triangle)$ 3 回 $\rightarrow 1$ 回、予測危険側失敗 $(x) 4$ 回 $\rightarrow 1$ 回之 なり、2 次予測のみの場合よりもかなり予測精度 の向上が実現できている。先に定義した成功率は 91\%となり、かなり的確な予測手法であることが 分かる。しかし、予測危険側失敗 $(\times)$ 1回を含 む以上、今後更に改良をしなければ使用できない。 その意味では、現状では参考的な予測手法として 使用する事は出来よう。

この時の採用予測值と観測值との関係を図 6 に 示している。図 $3(\mathrm{c})$ と比べると勾配 1 の直線に 近づいていることが分かる。

(2) 風と波 5 変数の場合の新たな判別

風と波を用いた波高予測では、予測值が観測值 よりも遅れるといら点はあるものの 1 次予測は 観測值と非常に近い值で推移する。このために平 均 2 乗誤差を用いてもその特徴をつかむことが出 来ず、風12変数の場合の予測の第 2 基準を 使らとかえって費用損失を多く生む結果と なる。

そこでこの場合には、平均 2 乗䛊差や波 高増加率を判別基準には使用せず、以下の ような基準を設定する。

第 3 基準 : 2 次予測值が $5 \mathrm{~m}$ 未満では 1 次予測值を採用

第 4 基準 : 2 次予測值が $5 \mathrm{~m}$ 以上では 2 次予測值を採用

この基準を用いた場合の評価結果を表 4 に示す。この結果は表 1 に示した結果と成 功率は同じであるが、2 次予測のみを用い る場合よりも、予測值は観測值により近く なっていることが分かる。

さらに表 4 を詳細に見れば分かるが、観 測波高は 1 次予測值もしくは 2 次予測值の いずれかにかなり近い。このことは 1 次予 測と 2 次予測の判別基準をもっとうまく選 ベば、予測精度の向上が期待できることを 示している。これは特に費用損失を引き起 こしている判別基準について言えることで、 さらに良好な判別基準の選定が今後に残さ れた課題と言える。

この時の採用予測值と観測值との関係を 図7に示している。図 3 (f) と比べると勾 配 1 の直線に近づいていることが分かる。

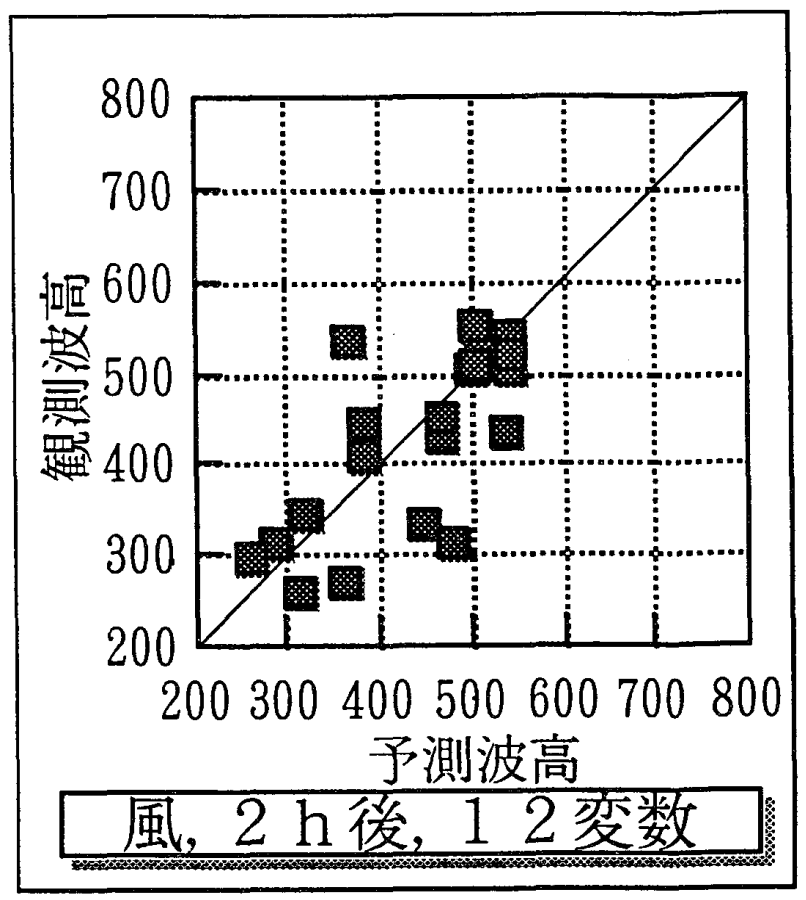

図 6 予测波高の改善

表 4 風と波を使用した予測手法の改善

\begin{tabular}{|c|c|c|c|c|c|c|c|c|c|c|c|c|}
\hline \multirow{3}{*}{ 月 } & \multirow{3}{*}{ 日 } & \multirow{3}{*}{ 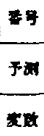 } & \multirow{3}{*}{ 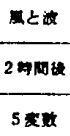 } & \multirow{3}{*}{ 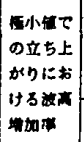 } & \multirow{2}{*}{\multicolumn{2}{|c|}{ 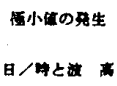 }} & \multirow{2}{*}{\multicolumn{2}{|c|}{ 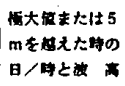 }} & \multirow{3}{*}{ 平然 2} & \multirow[t]{3}{*}{$\begin{array}{l}1 \text { to } \\
\text { fontix }\end{array}$} & \multirow{3}{*}{$\mid \begin{array}{ll}2 & x \\
\text { fint }\end{array}$} & \multirow[t]{3}{*}{ 要 用 } \\
\hline & & & & & & & & & & & & \\
\hline & & & & & 日/m & $(\mathrm{cm})$ & $\theta / m$ & $(\mathrm{~cm})$ & & & & \\
\hline \multirow{6}{*}{1} & $2-3$ & i & 0 & $57 \mathrm{ca} / 2 \mathrm{~h}$ & $2 / 18$ & 69 & $3 / 04$ & 258 & 848 & 268 & 362 & 268 \\
\hline & $4-5$ & 2 & 0 & $13 \mathrm{ca} / 2 \mathrm{~h}$ & $4 / 00$ & 120 & $5 / 06$ & 537 & 370 & 399 & 539 & 539 \\
\hline & $6-7$ & 3 & 0 & $205 \mathrm{ca} / 2 \mathrm{~h}$ & $6 / 22$ & 55 & $7 / 12$ & 507 & 9041 & 383 & 517 & 517 \\
\hline & $14-15$ & 4 & 0 & $9 \mathrm{ca} / 2 \mathrm{~h}$ & $14 / 00$ & sI & $15 / 01$ & 267 & 1557 & 298 & 100 & 296 \\
\hline & $17+18$ & 5 & o & $21 \mathrm{ca} / 2 \mathrm{~h}$ & $17 / 20$ & 165 & $19 / 22$ & 504 & 645 & 405 & 547 & 517 \\
\hline & 23 & 6 & 0 & $172 C_{w} / 2 \mathrm{~h}$ & $23 / 02$ & 35 & $23 / 06$ & 310 & 4499 & 335 & 452 & 335 \\
\hline \multirow{5}{*}{2} & $1-2$ & 7 & 0 & $4 \mid c a / 2 n$ & $1 / 08$ & 38 & $2 / 08$ & 542 & 689 & 422 & 569 & 569 \\
\hline & $7-8$ & 8 & 0 & Ick/2h & $7 / 08$ & 87 & $8 / 04$ & 345 & 588 & 342 & 461 & 342 \\
\hline & $9-10$ & 9 & $\Delta$ & $10 \mathrm{~cm} / 2 \mathrm{~h}$ & $9 / 14$ & 29 & $10 / 21$ & 426 & 1487 & 438 & 591 & 591 \\
\hline & $12-14$ & 10 & $\Delta$ & $35 \mathrm{~cm} / 2 \mathrm{~h}$ & $12 / 12$ & 156 & $14 / 02$ & 406 & 674 & $\$ 17$ & 563 & 563 \\
\hline & $21-22$ & 11 & 0 & $125 \mathrm{~cm} / 2 \mathrm{~h}$ & $22 / 00$ & 15 & $22 / 08$ & 539 & 19210 & 553 & 746 & 746 \\
\hline \multirow{3}{*}{11} & $21-22$ & 12 & 0 & $13 \mathrm{ca} / 2 \mathrm{~h}$ & $21 / 00$ & 35 & $22 / 10$ & 501 & 922 & 377 & 509 & 509 \\
\hline & $23-24$ & 13 & $\Delta$ & $78 \mathrm{ca} / 2 \mathrm{~h}$ & $23 / 14$ & 99 & $24 / 16$ & 435 & 1375 & 413 & 557 & 557 \\
\hline & $27-28$ & 14 & 0 & $80 \mathrm{~cm} / 2 \mathrm{~h}$ & $27 / 20$ & 73 & $28 / 14$ & 537 & 1985 & 426 & 575 & 575 \\
\hline \multirow{8}{*}{12} & 1 & 15 & 0 & $105 \mathrm{ca} / 2 \mathrm{~h}$ & $1 / 12$ & 27 & $1 / 18$ & 393 & 2612 & 339 & 458 & 339 \\
\hline & $2-3$ & 16 & 0 & $20 \mathrm{~cm} / 2 \mathrm{~h}$ & $2 / 18$ & 72 & $3 / 04$ & 295 & 1125 & 296 & 100 & 296 \\
\hline & $4-5$ & 17 & 0 & $39 \mathrm{~cm} / 2 \mathrm{~h}$ & $4 / 10$ & 192 & $5 / 02$ & 309 & 304 & 317 & 428 & 317 \\
\hline & 11 & 18 & 9 & $172 \mathrm{~cm} / 2 \mathrm{~h}$ & $11 / 12$ & 20 & $11 / 20$ & 551 & 20455 & 420 & 580 & 580 \\
\hline & $14-15$ & 19 & $\Delta$ & $26 \mathrm{~cm} / 2 \mathrm{~h}$ & $14 / 12$ & 173 & $15 / 14$ & 447 & 694 & 402 & 542 & 542 \\
\hline & 17 & 20 & 0 & $33 \mathrm{~cm} / 2 \mathrm{~h}$ & $17 / 04$ & 46 & $17 / 14$ & 518 & 7342 & 430 & 581 & 581 \\
\hline & $21-22$ & 21 & 0 & $8 \mathrm{ca} / 2 \mathrm{~h}$ & $21 / 06$ & 26 & $22 / 06$ & 508 & 1151 & 400 & 539 & 539 \\
\hline & $27-28$ & 22 & $\Delta$ & $0 \mathrm{cal} / 2 \mathrm{~h}$ & $27 / 00$ & 43 & $27 / 20$ & 448 & 2314 & 392 & 529 & 529 \\
\hline
\end{tabular}




\section{5. 結 語}

本研究により得られた主な結果をまとめると以 下の通りである。

（1）重回帰分析において変数として風速を用いる ことにより、70\%程度の成功率を持つ波高予測 が可能であることが分かった。

（2）風速12変数を用いての予測モデルでは、判別 基準として平均 2 乗誤差と極小值における波高 増加率を用いて $2 つ の$ 基準を設定することによ り、予測精度を $68 \%$ より $91 \%$ 一げることが出 来る。しかし予測危険側失敗（×）1回を含む 以上、今後更に改良を要するが参考的な予測手 法として使用できる。

（3）風と波を用いた波高予測では、予測值が観測 值よりも遅れるという欠点はあるものの 1 次予 測は観測值と非常に近い值で推移するために平 均 2 乗誤差を用いてむその特徴をつかむことが 出来ず、かえって費用損失を多く生む結果とな る。そこでこの場合には 2 次予測を主体にした

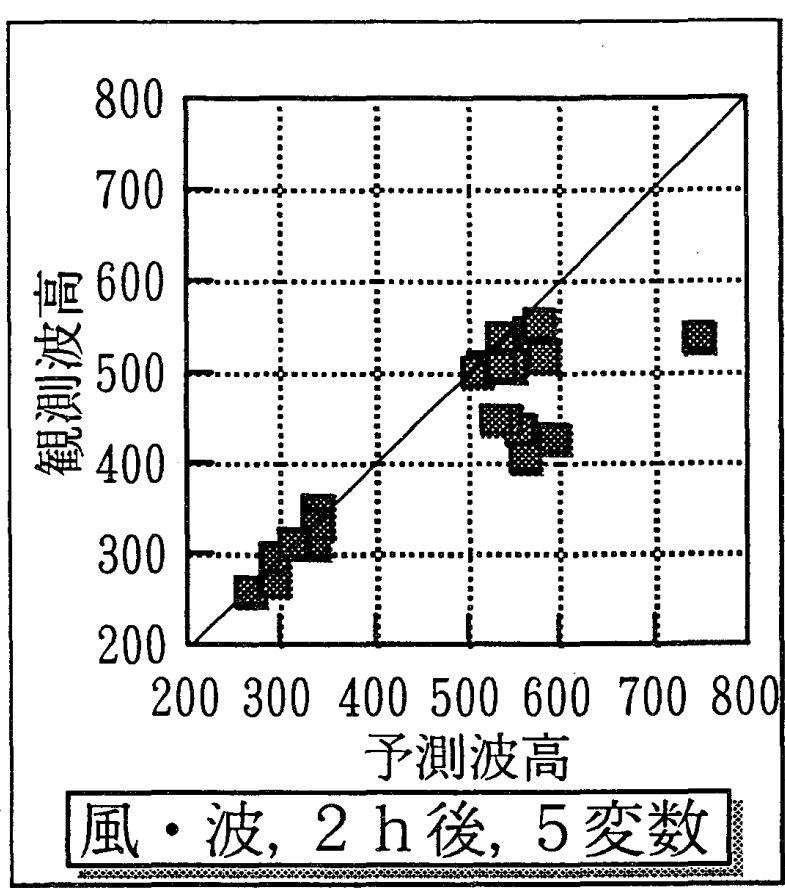

図 7 予測波高の改善 $2 つ の$ 基準を設定した。この予測手法では費用損失発生 $(\triangle)$ が 5 回生じるものの予測危険側失敗 $(\times)$ 0 回であることより安全側の予測手法といえる。

\section{参 考 文 献}

（1）白石 悟・ 久保雅義・上田 茂・榊原繁樹（1995）：係留システムに着目した長周期波に対する船舶 の動摇抑制対策, 海岸工学論文集第42卷, pp.941-945.

（2）永井紀彦-菅原一晃・橋本典明 - 浅井 正（1993）：沿岸波浪の日変動特性と波浪の特異日，港湾技 術研究所報告第32巻 第 2 号, pp.115-152.

（3） 久保雅義・小宗多惠・斎藤勝彦・笹 健児・津金正典・榊原繁樹（1997）：係留限界判断のための港 湾波浪統計利用に関する基礎的研究，日本航海学会論文集，第96号，pp.303-311.

（4）運輸省第一港湾建設局新潟調查設計事務所：観測台帳（統計編），風・潮位台帳（1992，1993，1994）。

（5）小舟浩治・橋本典明・渑山 豊・久高将信（1987）：重回帰式を用いた波浪予測手法の適用について, 第34回海岸工学講演会論文集, pp.167-171.

（6）太田隆夫・木村 晃（1996）：局所ファジィ再構成法を用いた波浪予測の試み，海岸工学論文集，第 43巻, pp. $241-245$.

（7）青野利夫・後藤智明・佐藤一央（1993）：沿岸波浪観測值を利用した重回帰波浪予測，港湾技術研究 所報告, 第32巻, 第 3 号, pp.39-63.

（8） 久保雅義・津金正典・笹 健児・榊原繁樹（1997）：係留限界を支配する諸要因に関する基礎的研究， 日本航海学会論文集，第96号，pp.313-322.

\section{質 疑 応 答}

和気博嗣（神戸商船大学）：1 次予測式に乗ずる比率（1.35）の值を変えた場合の影響は如何でしょうか。 久保雅義：この1.35といら比率は、1992年のデータを、そのまま予測式に代入して得た予測波高と $5 \mathrm{~m}$ 上の観測波高との比率の平均値として得られた值です。そのためこの比率を大きくすれば 2 次予測の值 が大きくなるため一般的には $5 \mathrm{~m}$ 以上の予測失敗 $(\times)$ のケースは減ります。例えば表 3 のケース 2 の 2 次予測は $5 \mathrm{~m}$ を越えますので 2 次予測としては成功します。この場合には第 2 基準を使用することを 提案しましたので、この場合の平均 2 乗誤差 $a=779 よ り 1$ 次予測採用となり、予測失敗を避けることは 
出来ません。

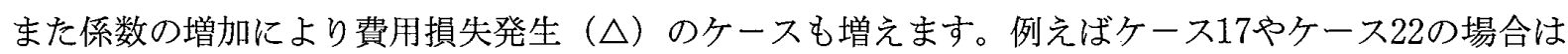
係数によっては○一ーとなります。

さらにこの 22 ケスのみで最む適した係数を設定することは作為的になりすぎますので、ここではあ くまでも平均值で議論を進めています。比率の変化による改善法でなく、他の根本的改善法を以後検討 したく考えています。 